\title{
PENGARUH LIMBAH AMPAS KOPI DAN MACAM MEDIA TERHADAP PERTUMBUHAN DAN HASIL TANAMAN SORGUM DI POLYBAG
}

\section{(THE EFFECT OF COFFEA WASTE AND MEDIA KIND ON GROWTH AND YIELD SORGHUM IN POLYBAG)}

\author{
Sartono Joko Santosa \\ Fakultas Pertanian Universitas Slamet Riyadi
}

\begin{abstract}
ABSTRAK
Dalam teknologi budidaya pertanian terdapat unsur hata yang sangat berpengaruh terhadap pertumbuhan dan hasil tanaman. Salah satu unsur hara yang alami dan mudah mendapatkannya serta banyak tersedia adalah air limbah ampas kopi dan media tanam. Penelitian yang berjudul Pengaruh Limbah Ampas Kopi dan Macam Media terhadap Pertumbuhan dan Hasil Tanaman Sorgum di Polybag bertujuan untuk mengetahui pengaruh dosis limbah ampas kopi dan macam media terhadap pertumbuhan dan hasil tanaman sorgum di polybag, dilaksanakan bulan April sampai Agustus 2018, di Green House Fakultas Pertanian UNISRI Mojosongo. Dengan ketinggian tempat $140 \mathrm{mdpl}$, jenis tanah grumosol. Metode penelitian yang digunakan yaitu Rancangan Acak Lengkap (RAL) dengan dua faktor perlakuan dan tiga kali ulangan. Peubah yang digunakan yaitu Tinggi tanaman, Jumlah daun, Berat segar brangkasan, Berat kering brangkasan, Jumlah biji per malai, Berat 100 biji dan berat kering biji per malai. Hasil penelitian menunjukkan bahwa Pemberian dosis limbah ampas kopi berpengaruh terhadap berat segar brangkasan dan berat kering biji per malai, Pemberian macam media tanam tidak berpengaruh terhadap semua parameter pengamatan serta tidak terdapat interaksi antara pemberian dosis limbsh ampas kopi dan macam media tanam terhadap semua parameter pengamatan tanaman sorgum
\end{abstract}

Kata kunci : Limbah ampas kopi, media tanam, sorgum, polybag

\section{ABSTRACT}

In agricultural cultivation technology there are growth regulators that are very influential on the growth and yield of plants. One of the natural and easy-to-gain are coffea waste and planting media. The research entitled The Effect of Coffea waste dosage and kind of planting media to Growth and Yield Sorghum in Polybag was done April till August 2018 in Green House Mojosongo, Agriculture Faculty UNISRI with altitude $140 \mathrm{mdpl}$ in grumosol soil type. The research method used was Randomized Complete Design (RCD) with two factor treatment and three replications. The parameters observed was height of plant, number of leaves, fresh weight of biomass, dry weight of biomas, number of weed per stole, dry weight weed per stole and dry weight 100 weeds. The results of the reseach showed that (1) Giving coffea waste dosage was significant effect to fresh weight of biomass and number of weed per stole, (2) Giving planting media wasn't significant effect to all parametrs observed and (3) was't interaction between Giving coffea waste dosage and planting media to all parameters observed.

Keywords: coffe waste, planting media, sorghum, polybag 


\section{PENDAHULUAN}

Sorgum (Sorghum bicolor L.) adalah tanaman serealia yang potensial untuk dibudidayakan dan dikembangkan, khususnya pada daerah-daerah marginal dan kering di Indonesia. Keunggulan sorgum terletak pada daya adaptasi agroekologi yang luas, tahan terhadap kekeringan, produksi tinggi, perlu input lebih sedikit serta lebih tahan terhadap hama dan penyakit dibading tanaman pangan lain. Selain itu, tanaman sorgum memiliki kandungan nutrisi yang tinggi, sehingga sangat baik digunakan sebagai sumber bahan pangan maupun pakan ternak alternatif.(Sofyadi,2011)

Biji sorgum yang mengandung karbohidrat cukup tinggi sering digunakan sebagai bahan baku bermacam industri seperti industri beer, pati, gula cair (sirup), jaggery (semacam gula merah), etanol, lem, cat, kertas, degradable plastics dan lain-lain. Adapula jenis sorghum yang batangnya mengandung kadar gula cukup tinggi dan disebut sorgum manis (sweet sorghum). Sorgum manis sangat ideal digunakan untuk pakan ternak ruminansia, gula cair (sirup), jaggery dan bioetanol .

Tanaman sorgum banyak membutuhkan pupuk N (Nitrogen), Namun demikian pemupukan sebaiknya diberikan secara lengkap (NPK) agar produksi yang dihasilkan cukup tinggi. Dosis pemupukan yang diberikan berbeda-beda tergantung pada tingkat kesuburan tanah dan varietas yang ditanam, tetapi secara umum dosis yang dianjurkan adalah $200 \mathrm{~kg}$ Urea, $100 \mathrm{~kg}$ TSP atau SP36 dan $50 \mathrm{~kg} \mathrm{KCl.}$

Limbah ampas kopi pada umumnya dibuang dan menjadi limbah rumah tangga. Padahal berdasarkan pengalaman di lapangan limbah ampas kopi dapat menyuburkan tanaman ketika dibuang disamping tanaman dan dapat berperan sebagai pestisida organik.

Pembuangan ampas kopi berimplikasi pada meningkatnya volume sampah di tempat pembuangan akhir (TPA). Kalau ampas kopi (dan kertas filter) anda terbuang begitu saja, bisa dipastikan anda secara tidak langsung menyumbang penumpukan sampah. Untuk mengatasi hal tersebut, maka perlu memanfaatkan limbah ampas kopi tersebut agar tidak menjadi limbah yang tidak berguna, tetapi justru dapat memanfaatkannya untuk kesuburan tanaman ataupun untuk pestisida organik. 
Ampas kopi merupakan pupuk organik yang ekonomis dan ramah lingkungan. Ampas kopi mengandung 2,28\% nitrogen, fosfor 0,06\% dan 0,6 kalium. $\mathrm{pH}$ ampas kopi sedikit asam, berkisar 6,2 pada skala $\mathrm{pH}$. Selain itu, ampas kopi mengandung magnesium, sulfur, dan kalsium yang berguna bagi pertumbuhan tanaman (Anonim, 2012 b)

Selain bermanfaat untuk tubuh, nutrisi pada kopi juga bermanfaat untuk tanah, karena ampas kopi mengandung magnesium, kalsium, potasium, fosfor, dan nitrogen yang biasanya terkandung pada pupuk.Tanah yang bernutrisi karena adanya limbah ampas kopi cenderung mengundang cacing untuk membantu menggemburkan tanah. Beberapa tanaman buah seperti alpukat, jambu biji, tomat, dan terung menyukai tanah yang ditambah kopi (Anonim, 2017).

Sebaran bubuk kopi di sekitar tanaman akan mencegah datangnya bekicot, siput, semut dan hewan pemakan daun lainnya yang bertubuh lunak. Ampas kopi juga dapat mencegah munculnya ulat di daun karena kupu-kupu jadi tidak tertarik untuk bertelur pada daunnya. Kupu-kupu hanya tertarik dengan bunganya dan tidak ingin bertengger terlalu lama di sekitar daun karena aroma kopinya

Tanaman yang disiram limbah ampas kopi pertumbuhannya lebih baik dibandingkan dengan yang tidak diberi limbah ampas kopi. Hal ini menunjukkan bahwa, limbah ampas kopi dapat dimanfaatkan sebagai pupuk bagi tanaman. Kandungan hara ampas kopi mengandung 2,28\% nitrogen, fosfor 0,06\% dan 0,6 kalium. $\mathrm{pH}$ ampas kopi sedikit asam, berkisar 6,2 pada skala pH. Selain itu, ampas kopi mengandung magnesium, sulfur, dan kalsium yang berguna bagi pertumbuhan tanaman, namun, secara ilmiah perlu dibuktikan kebenarannya (Anonim, 2012)

Media tanam dapat diartikan sebagai tempat tinggal atau rumah bagi tanaman. Tempat tinggal yang baik adalah yang dapat mendukung pertumbuhan dan kehidupan tanaman (Agoes, 1994). Tanah sebagai media bercocok tanam memiliki beberapa kekurangan, yaitu bekerja tidak bersih, penggunaan nutrient oleh tanaman kurang efisien, banyak gulma, dan pertumbuhan tanaman kurang terkontrol. Alternatif pemecahan masalah yaitu dengan mencari bahan-bahan selain tanah dan tanpa membutuhkan lahan yang luas untuk bercocok tanam. Berbagai bahan media tanam yang digunakan harus tetap mendukung pertumbuhan dan perkembangan tanaman sehingga produktivitasnya dapat menjadi lebih baik. 
Media tanam campuran dari tanah, pupuk kandang, arang sekam dan pasir dapat mendukung pertumbuhan dan perkembangan tanaman selada. Tanah berfungsi untuk tumbuh tegaknya tanaman, pupuk kandang dapat memperbaiki sifat tanah seperti fisik, kimia dan biologi. Arang sekam memiliki peranan penting sebagai media tanam pengganti tanah karena bersifat porous, ringan, tidak kotor dan cukup dapat menahan air. Pasir berfungsi untuk meloloskan air, sehingga tanah tidak terlalu lembab (Anonim, 2012).

Media pasir memiliki aerasi (ketersediaan rongga udara) dan draenase yang baik, namun pasir mempunyai luas permukaan komulatif yang relatif kecil, sehingga kemampuan menyimpan airnya sangat rendah atau tanahnya lebih cepat kering. Kemampuan menyimpan unsur hara pada pasir juga sangat rendah, sehingga unsur hara yang diberikan melalui pemupukan cepat hanyut terbawa air keluar dari area perakaran (Nivizan, 2002)

Pupuk kandang juga dapat digunakan sebagai media tanam. Pupuk kandang adalah pupuk yang berasal dari kotoran ternak baik berupa kotoran padat (feces) yang bercampur sisa makanan maupun air keccing (urine). Pupuk kandang sapi meupakan pupuk padat yang banyak mengandung air dan lendir. Bagian padatan mudah terpengaruh oleh udara sehingga cepat terjadi pergerakan pergerakan air ke udara dan menjadi keras (Soegiman, 1992).

Sekam merupakan salah satu campuran media tanam yang dapat mengikat air dan merupakan bahan unsur hara alami yang dapat memberikan tanaman karena sifatnya yang remah dan strukturnya mudah menyimpan oksigen. Perakaran tanaman akan tumbuh dengan sempurna apabila air tercukupi dan oksigen da;lam tanah tersedia (Anonim, 2012)

\section{METODE PENELITIAN}

\section{A. BAHAN DAN ALAT PENELITIAN}

Bahan yang digunakan dalam penelitian ini adalah Benih Sorgum, Limbah ampas kopi, , Tanah Jenis Grumusol, Pupuk Kandang, Sekam, Pasir

Alat yang digunakan dalam penelitian ini adalah Polibag berukuran $45 \mathrm{~cm}$ x $45 \mathrm{~cm}$, Jangka sorong, Cangkul, Oven, Cetok, Tali, Alat tulis, Botol 1,5 Liter, Penggaris, Gelas Air Mineral, Label, Bambu (Ajir), Ember.

\section{B. RANCANGAN PENELITIAN.}


Penelitian ini menggunakan Rangcangan faktorial dengan pola dasar Rancangan Acak Lengkap (RAL) dan terdiri atas dua faktor perlakuan, dan tiga kali ulangan. Adapun kedua faktor perlakuan tersebut adalah sebagai berikut :

1. Faktor perlakuan dosis limbah ampas kopi (K), yang terdiri atas 4 taraf :

Ko $=$ Tanpa Limbah ampas kopi

$\mathrm{K}_{1}=$ Limbah ampas kopi $5 \mathrm{gr} / \mathrm{L}$

$\mathrm{K}_{2}=$ Limbah ampas kopi $10 \mathrm{gr} / \mathrm{L}$

$\mathrm{K}_{3}=$ Limbah ampas kopi $15 \mathrm{gr} / \mathrm{L}$.

2.Faktor perlakuan macam media tanam (M), yang terdiri atas 3 macam :

$\mathrm{T}_{1}=$ Media tanam campuran tanah $:$ pupuk kandang

$\mathrm{T}_{2}=$ Media tanam campuran tanah : pupuk kandang : sekam

$\mathrm{T}_{3}=$ Media tanam campuran tanah : pupuk kandang : pasir

Sehingga secara keseluruhan dapat diperoleh 12 kombinasi perlakuan yaitu:

$\mathrm{K}_{0} \mathrm{~T}_{1}=$ Tanpa ampas kopi dan Media tanam campuran tanah : pupuk kandang $\mathrm{K}_{1} \mathrm{~T}_{1}=$ Ampas kopi $5 \mathrm{gr} / \mathrm{L}$ dan Media tanam campuran tanah : pupuk kandang $\mathrm{K}_{2} \mathrm{~T}_{1}=$ Ampas kopi $10 \mathrm{gr} / \mathrm{L}$ dan Media tanam campuran tanah : pupuk kandang $\mathrm{K}_{3} \mathrm{~T}_{1}=$ Ampas kopi $15 \mathrm{gr} / \mathrm{L}$ dan Media tanam campuran tanah : pupuk kandang $\mathrm{K}_{0} \mathrm{~T}_{2}=$ Tanpa Ampas kopi dan Media tanam tanah : pupuk kandang : sekam $\mathrm{K}_{1} \mathrm{~T}_{2}=$ Ampas kopi $5 \mathrm{gr} / \mathrm{L}$ dan Media tanam tanah : pupuk kandang : sekam $\mathrm{K}_{2} \mathrm{~T}_{2}=$ Ampas kopi $10 \mathrm{gr} / \mathrm{L}$ dan Media tanam tanah : pupuk kandang : sekam $\mathrm{K}_{3} \mathrm{~T}_{2}=$ Ampas kopi $15 \mathrm{gr} / \mathrm{Ldan}$ Media tanam tanah : pupuk kandang : sekam $\mathrm{K}_{0} \mathrm{~T}_{3}=$ Tanpa Ampas kopi dan Media tanam tanah : pupuk kandang : pasir $\mathrm{K}_{1} \mathrm{~T}_{3}=$ Ampas kopi $5 \mathrm{gr} / \mathrm{L}$ dan Media tanam tanah : pupuk kandang : pasir $\mathrm{K}_{2} \mathrm{~T}_{3}=$ Ampas kopi $10 \mathrm{gr} / \mathrm{L}$ dan Media tanam tanah : pupuk kandang : pasir $\mathrm{K}_{3} \mathrm{~T}_{3}=$ Ampas kopi $15 \mathrm{gr} / \mathrm{L}$ dan Media tanam tanah : pupuk kandang : pasir Setiap perlakuan diulang 3 kali dan data hasil penelitian dianalisis menggunakan analisis keragaman dengan taraf nyata 5\%,

Perubah yang digunakan yaitu :

1 Tinggi Tanaman (cm)

2.Jumlah Daun (helai) 
3, Berat Segar Brangkasan (g)

4. Berat kering Brangkasan (g)

5.Berat biji per malai (g)

6.Berat 100 biji (g)

7.Jumlah biji per malai

\section{ANALISA DATA}

Data yang diperoleh dianalisis dengan Analisis Sidik Ragam, bila terdapat perlakuan yang menunjukkan beda nyata dilanjutkan dengan Uji Jarak Berganda Duncan

\section{WAKTU DAN TEMPAT PENELITIAN}

Penelitian dilaksanakan mulai bulan April 2018 dan berakhir pada bulan Agustus 2018. di Green house Fakultas Pertanian Universitas Slamet Riyadi yang berlokasi di Kelurahan Mojosongo, Kecamatan Jebres, Kota Surakarta Propinsi Jawa Tengah.

\section{HASIL PENELITIAN DAN PEMBAHASAN}

\section{Pertumbuhan Tanaman Sorgum}

\begin{tabular}{|c|c|c|c|c|}
\hline Perlakuan & $\begin{array}{l}\text { Tinggi } \\
\text { Tanaman }\end{array}$ & $\begin{array}{l}\text { Jumlah } \\
\text { Daun }\end{array}$ & $\begin{array}{l}\text { Brt. Segar } \\
\text { brangkasan }\end{array}$ & $\begin{array}{l}\text { Brt. Kering } \\
\text { brangkasan }\end{array}$ \\
\hline K0T1 & $205,00 \mathrm{a}$ & $8,67 \mathrm{a}$ & 493,33 a & 94,75 a \\
\hline K1T1 & $206,67 \mathrm{a}$ & $8,00 \mathrm{a}$ & $350,00 \mathrm{~b}$ & 64,45 a \\
\hline K2T1 & 198,67 a & 7,33 a & 466,67 a & 111,51 a \\
\hline K3T1 & $216,00 \mathrm{a}$ & 8,67 a & $470,00 \mathrm{ab}$ & $102,47 \mathrm{a}$ \\
\hline K0T2 & $205,00 \mathrm{a}$ & $9,00 \mathrm{a}$ & 496,67 a & 95,44 a \\
\hline K1T2 & 203,33 a & 8,33 a & $443,33 \mathrm{~b}$ & $93,41 \mathrm{a}$ \\
\hline K2T2 & $204,00 \mathrm{a}$ & $8,67 \mathrm{a}$ & 553,33 а & 113,62 a \\
\hline K3T2 & $190,67 \mathrm{a}$ & $8,67 \mathrm{a}$ & $450,00 \mathrm{ab}$ & 78,03 a \\
\hline K0T3 & 206,67 a & 8,33 a & 530,00 a & 118,17 a \\
\hline K1T3 & $216,00 \mathrm{a}$ & $8,00 \mathrm{a}$ & $350,00 \mathrm{~b}$ & $64,45 \mathrm{a}$ \\
\hline K2T3 & 203,33 a & $9,00 \mathrm{a}$ & 443,33 a & $93,41 \mathrm{a}$ \\
\hline K3T3 & $217,33 \mathrm{a}$ & $8,67 \mathrm{a}$ & $450,00 \mathrm{ab}$ & $118,17 \mathrm{a}$ \\
\hline
\end{tabular}

Keterangan : rata-rata angka pertumbuhan yang diikuti huruf yang sama pada kolom yang sama berarti tidak berbeda nyata

Pemberian dosis limbah ampas kopi dan macam media tanam tidak memberikan pengaruh pada tinggi tanaman, jumlah daun dan berat kering brangkasan tetapi memberikan pengaruh pada berat segar brangkasan. 
Kandungan yang terdapat pada ampas kopi yaitu sulfur, magnesium dan kalsium yang berguna bagi pertumbuhan tanaman. Sari (2016) berpendapat penggunaan media tanam yang dicampur Tanah,Arang Sekam, Pupuk Kandang Ayam dengan perbandingan 1:1:1 dapat membantu meningkatkan kandungan $\mathrm{N}$ dalam tanah, sehingga mempengaruhi pertumbuhan dan hasil tanaman sawi pak choi menjadi lebih tinggi.

Unsur hara esensial yang terdapat pada limbah ampas kopi dan media tanam adalah magnesium dan Nitrogen. Poerwowidodo (1993) menyatakan peran magnesium terhadap tanaman sebagai aktivator dalam transportasi pembentukan logam klorofil didalam tanaman. Syarief (1993) menambahkan bahwa pupuk nitrogen dibutuhkan tanaman guna pembentukan, pertumbuhan pada bagian vegetatif tanaman seperti daun, batang dan akar. Hal ini didukung oleh penelitian Adikasari, (2012) menyatakan bahwa ampas kopi dapat digunakan untuk penambah nutrisi terhadap pertumbuhan tanaman tomat (Solanum lycopersicum) dengan media tanam hidroponik meningkatkan tinggi tanaman tomat. Namun tidak nampak berbeda nyata pada pertumbuhan tanaman sorgum.

Pemberian limbah ampas kopi dan macam media tanam berbeda tidak nyata pada jumlah daun. Hal ini diduga karena hasil dari fotosintesis lebih banyak dimanfaatkanpada pertambahan tinggi tanaman. Lakitan (1996) menyatakanbahwa pertumbuhan tanaman tidak berlangsung secara bersamaan pada seluruh bagian tanaman. Pertumbuhan lebih terfokus pada jaringan meristem batang sehingga terjadi pembesaran sel dari pembelahan sel tersebut yang mengakibatkan pertambahan pada ukuran tanaman.

Meningkat dan berkurangnya bobot segar dan bobot kering brangkasan terkait dengan tinggi tanaman dan jumlah daun, yang dipengaruhi dari hasil laju fotosintesis suatu tanaman. Daun berperan penting dalam organ fotosintesis yang merupakan produsen utama fotosintat sehingga dapat dijadikan indikator pertumbuhan terutama guna menjelaskan proses pembentukan biomassa (Sitompul dan Guritno, 1995). Proses fisiologi pada tanaman merupakan faktor yang mempengaruhi berat brangkasan segar karena terjadinya serapan air dan hara mineral pada medium habitatnya melalui akar yang disebut deplasmolisis (Eka dan Triyono, 2016). Pertumbuhan akar yang baik dapat mempengaruhi serapan hara dan air pada tanaman. Sedangkan serapan hara dan air mempengaruhi berat segar brangkasan karena air merupakan faktor utama yang berpengaruh pada berat brangkasan segar. Cahaya yang ditertangkap selama proses fotosintesis menggambarkan besarnya biomassa yang ada, dan besarnya biomassa pada jaringan tanaman menunjukan berat kering tanaman (Tohari $d k k$, 2004) 
Berkurangya berat basah tanaman yang terkait dengan tinggi tanaman dan jumlah daun, secara bersamaan akan menurunkan berat kering brangkasan, karena besar atau tidaknya berat kering brangkasan tergantung dari berat basah brangkasan. Semakin besar berat basah brangkasan akan mempengaruhi berat kering brangkasan, dan begitu pula sebaliknya jika berat basah brangkasan semakin menurun maka berat kering brangkasan juga akan ikut menurun. Menurut Gardner dalam Susanti (2011), berat kering tanaman budidaya merupakan penimbunan hasil asimilasi $\mathrm{CO}_{2}$ sepanjang masa pertumbuhan.

Diagram Pemberian limbah ampas kopi dan macam media tanam terhadap tinggi tanaman menunjukkan bahwa tinggi tanaman tertinggi pada perlakuan (K3T3 ) dosis limbah ampas kopi 15 g/l dengan media tanam campuran tanah, pupuk kandang dan pasir yaitu 217,38 cm, sedangkan terpendek pada (K3T2 ) dosis limbah ampas kopi 15 g/l dengan media tanam campuran tanah, pupuk kandang dan sekam yaitu 190,67 cm

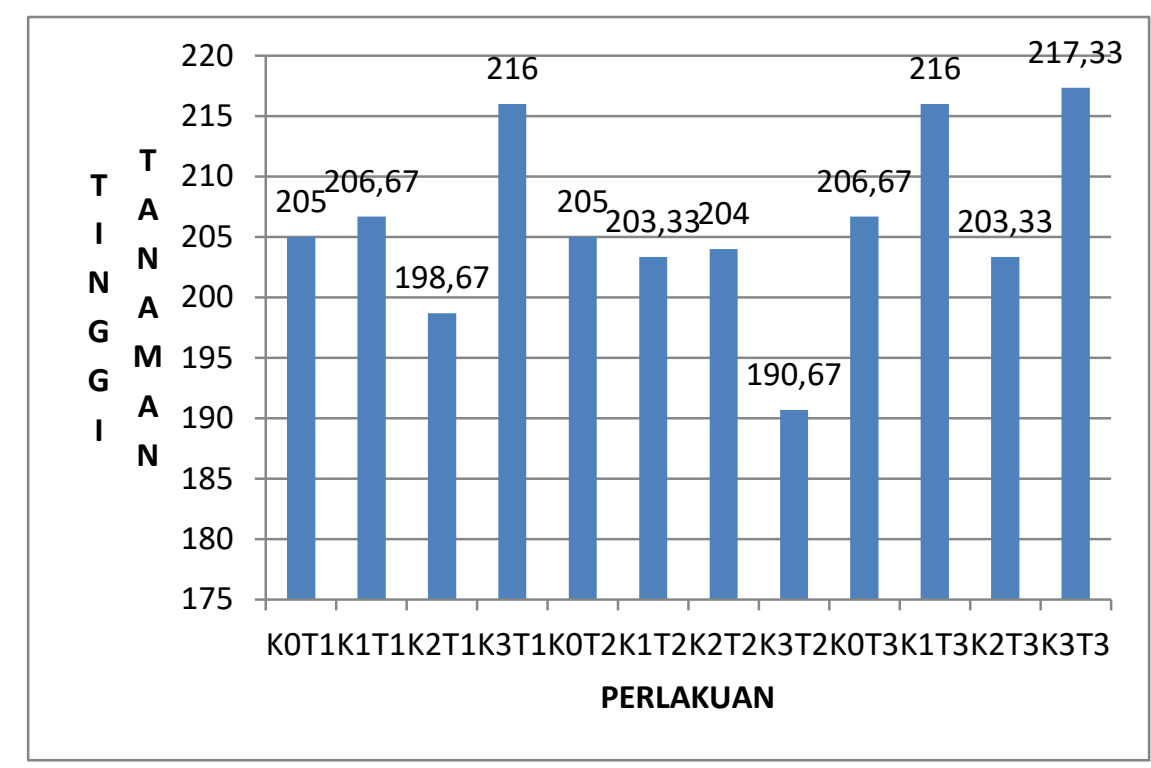

Diagram Pemberian limbah ampas kopi dan macam media tanam

terhadap jumlah daun menunjukkan bahwa jumlah daun terbanyak pada perlakuan (K0T2) tanpa limbah ampas kopi dengan media tanam campuran tanah, pupuk kandang dan sekam serta (K2T3 ) dosis limbah ampas kopi 10 g/l dengan media tanam campuran tanah, pupuk kandang dan pasir yaitu 9, sedangkan jumlah daun paling sedikit pada (K2T2 ) dosis limbah ampas kopi 10 g/l dengan media tanam campuran tanah, pupuk kandang dan sekam yaitu 7,35 


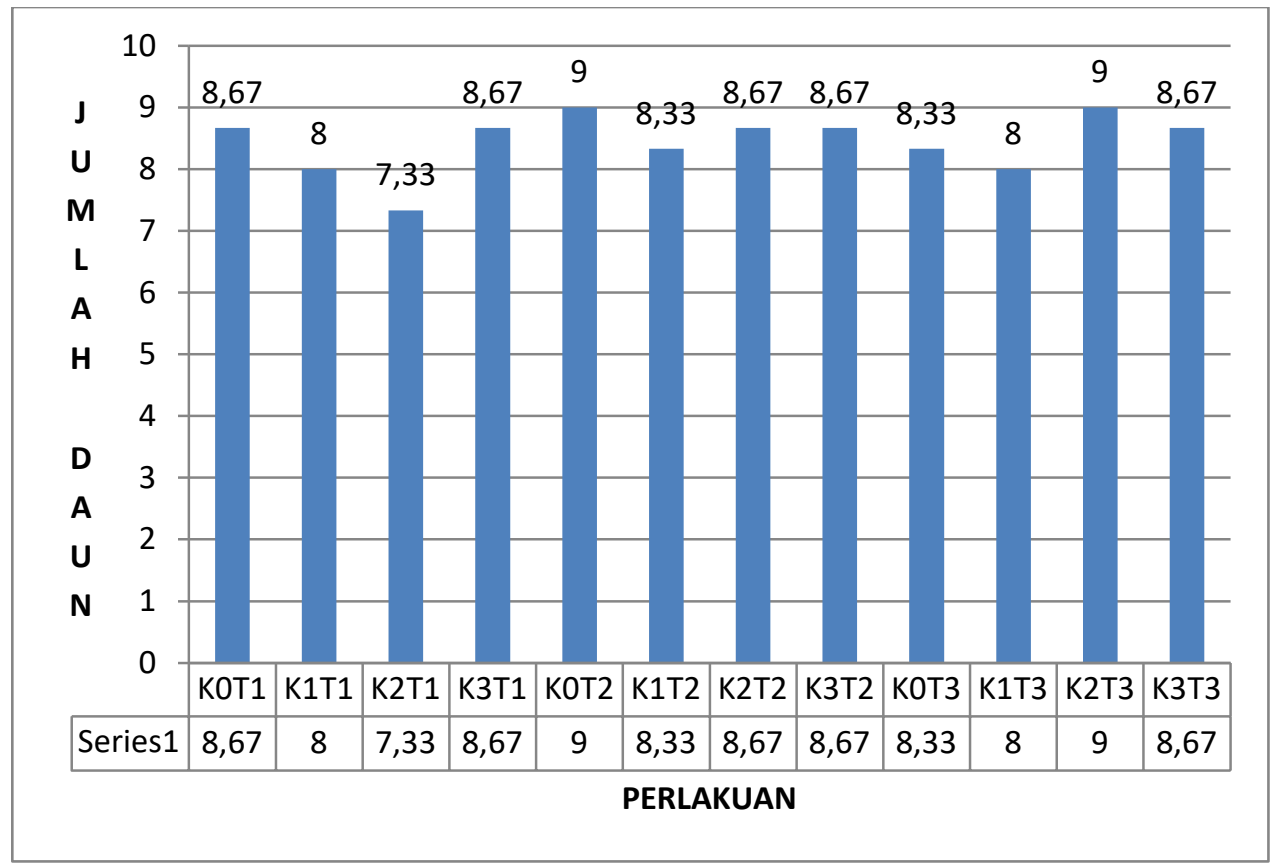

Diagram Pemberian limbah ampas kopi dan macam media tanam

terhadap berat segar brangkasan menunjukkan bahwa berat segar brangkasan tertinggi pada perlakuan (K2T2) dosis limbah ampas kopi 10 g/l dengan media tanam campuran tanah, pupuk kandang dan sekam yaitu 553,33 g, sedangkan terendah pada (K1T1) dosis limbah ampas kopi 5 g/l dengan media tanam campuran tanah, pupuk kandang serta (K1T3) dosis limbah ampas kopi 5 g/l dengan media tanam campuran tanah, pupuk kandang dan pasir yaitu $190,67 \mathrm{~cm}$

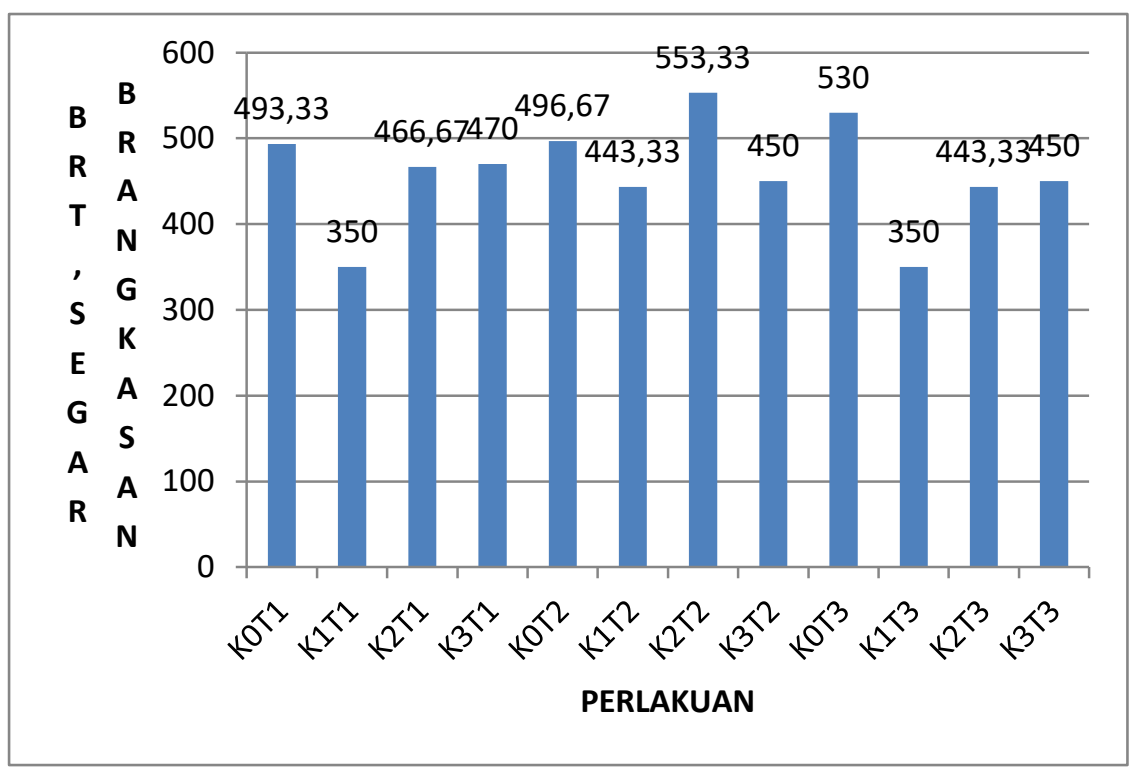


Diagram Pemberian limbah ampas kopi dan macam media tanam

terhadap berat kering brangkasan menunjukkan bahwa berat kering brangkasan tertinggi pada perlakuan (K0T3) tanpa limbah ampas kopi dengan media tanam campuran tanah, pupuk kandang dan pasir serta (K3T3 ) dosis limbah ampas kopi 15 g/l dengan media tanam campuran tanah, pupuk kandang dan pasir yaitu 118,17 g, sedangkan berat kering brangkasan terendah pada (K1T1 ) dosis limbah ampas kopi 5 g/l dengan media tanam campuran tanah, pupuk serta (K1T3) dosis limbah ampas kopi 5 g/l dengan media tanam campuran tanah, pupuk kandang dan pasir yaitu 64,45 g.

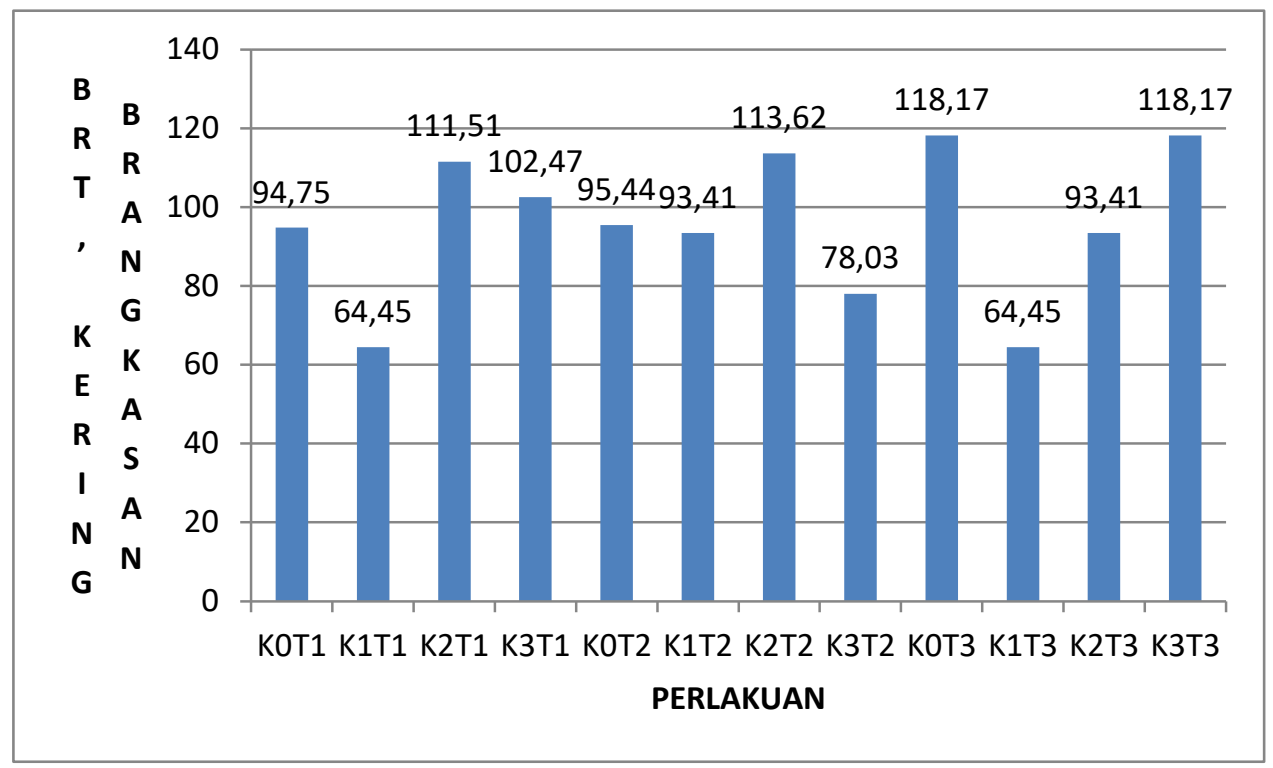

2. Hasil Tanaman Sorgum

\begin{tabular}{|c|c|c|c|}
\hline Perlakuan & $\begin{array}{l}\text { Jumlah biji per } \\
\text { malai }\end{array}$ & $\begin{array}{l}\text { Berat } 100 \text { biji } \\
\text { kering per malai }\end{array}$ & $\begin{array}{l}\text { Berat kering biji } \\
\text { per malai }\end{array}$ \\
\hline K0T1 & 1917,00 a & 3,99 a & $76,83 \mathrm{~b}$ \\
\hline K1T1 & 1148,33 a & 3,78 a & 41,79 a \\
\hline K2T1 & 1666,33 a & $3,90 \mathrm{a}$ & $65,56 \mathrm{ab}$ \\
\hline K3T1 & 1508,00 a & $3,71 \mathrm{a}$ & $56,25 \mathrm{ab}$ \\
\hline K0T2 & $1426,67 \mathrm{a}$ & $4,14 \mathrm{a}$ & $59,33 \mathrm{~b}$ \\
\hline K1T2 & 1432,00 a & $3,69 \mathrm{a}$ & $53,93 \mathrm{a}$ \\
\hline K2T2 & $1543,33 \mathrm{a}$ & $4,00 \mathrm{a}$ & $61,93 \mathrm{ab}$ \\
\hline K3T2 & $1732,33 \mathrm{a}$ & $3,33 \mathrm{a}$ & $58,09 \mathrm{ab}$ \\
\hline K0T3 & $1511,00 \mathrm{a}$ & $3,97 \mathrm{a}$ & $58,51 \mathrm{~b}$ \\
\hline K1T3 & $1148,33 \mathrm{a}$ & $3,78 \mathrm{a}$ & $53,93 \mathrm{a}$ \\
\hline K2T3 & $1432,00 \mathrm{a}$ & $3,69 \mathrm{a}$ & $53,93 \mathrm{ab}$ \\
\hline K3T3 & $1511,00 \mathrm{a}$ & $3,97 \mathrm{a}$ & $58,51 \mathrm{ab}$ \\
\hline
\end{tabular}

Keterangan : rata-rata angka pertumbuhan yang diikuti huruf yang sama pada kolom yang sama berarti tidak berbeda nyata 
Pemberian macam limbah ampas kopi dan komposisi media tanam tidak memberikan pengaruh nyata pada hasil tanaman sorgum yaitu terhadap, berat 100 biji per malai, dan jumlah biji per malai, tetapi memberikan pengaruh pada berat biji kering pertmalai.

Hal ini diduga karena adanya keterkaitan terhadap pertumbuhan tanaman dan pemanfaatan hara tanaman serta proses fisiologi tanaman yang mempengaruhi hasil pembentukan biji. Sebagaiamana pernyataan Sunarto (2004) menyatakan kandungan N selalu berkaitan dengan sintesis klorofil, sintesis protein dan enzim. Enzim (rubisco) berguna sebagai katasilator dalam fiksasi CO2 yang dibutuhkan oleh tanaman untuk proses fotosintesis. Penurunan kadar nitrogen pada tanaman dapat menyebabkan kinerja fotosintesis baik lewat kandungan klorofil ataupun enzim fotosintetik yang mempengaruhi terhadap penurunan pada pati (fotosintat) yang dibentuk.

Jumlah biji berkaitan dengan besar kecilnya biji yang diproduksi, apabila tanaman menghasilkan biji banyak maka ukuran biji lebih kecil dan sebaliknya apabila jumlah biji sedikit maka ukuran biji besar yang ditunjukan dengan berat 100 biji. Egli (1999) mengungkapkan bahwa produktivitas tanaman dibatasi oleh aktivitas fotosintesis source atau kemampuan sink untuk menggunakan asimilat yang dihasilkan source. Sehingga terjadinya perubahan akumulasi bahan kering atau perubahan indeks panen (partisi asimilasi) atau keduanya dapat terjadi akibat perubahan faktor produksi yang dapat mempengaruhi hasil jumlah dan ukuran biji.

Faktor yang mempengaruhi hasil produksi tanaman, selain dari perlakuan ada kemungkinan unsur hara yang berada dimedia tanam (tanah) sudah tercukupi. Sehingga pemberian perlakuan tidak berpengaruh pada hasil sorgum. Sebagimana pendapat Darmawijaya (1990) mengungkapkan pada umumnya tanah aluvial sepanjang aliran besar merupakan campuran yang mengandung cukup banyak hara bagi tanaman, sehingga dianggap tanah subur. Tanah aluvial identik dengan warna yang coklat-pucat (pale brown) dengan tekstur lempung ringan, yang terdiri atas susunan pasir 30\%, debu 35\%, lempung $35 \%$, bertekstur remah, konsistensi liat-lekat dan permeabilitas sedang. Serta sifat kimia tanah yang cukup baik yang terdiri dari $\mathrm{P}_{2} \mathrm{O}_{5}$ 0,06\%, $\mathrm{K}_{2} \mathrm{O}$ 0,05\%, $\mathrm{CaO}$ 1b5, MgO 0,400\%, dan $\mathrm{P}_{2} \mathrm{O}_{5}$ 0,025\%, .

Darmawan dan Baharsyah (1983) mengungkapkan bahwa ketersediaan unsur hara yang cukup dan seimbang dapat mempengaruhi metabolisme pada tanaman. Proses metabolisme yaitu pembentukan dan perombakan unsur- unsur hara dan senyawa organik dalam tubuh tanaman untuk menunjang pertumbuhan dan perkembangan tanaman. Selanjutnya Dwijoseputro (1986) menambahkan bahwa suatu tanaman akan tumbuh dan berkembang 
dengan baik apabila unsur hara yang dibutuhkan oleh tanaman berada dalam jumlah yang cukup dan berada dalam bentuk yang siap diabsorbsi.

Diagram Pemberian dosis limbah ampas kopi dan macam media tanam terhadap jumlah biji per malai menunjukkan bahwa jumlah biji tertinggi pada perlakuan (K0T1 ) tanpa limbah ampas kopi dengan media tanam campuran tanah, pupuk kandang yaitu 1917 buah, sedangkan terendah pada (K1T1 ) dosis limbah ampas kopi 5 g/l dengan media tanam campuran tanah, pupuk kandang dan pada (K1T3 ) dosis limbah ampas kopi 5 g/l dengan media tanam campuran tanah, pupuk kandang , pasir yaitu 1148,33 buah.

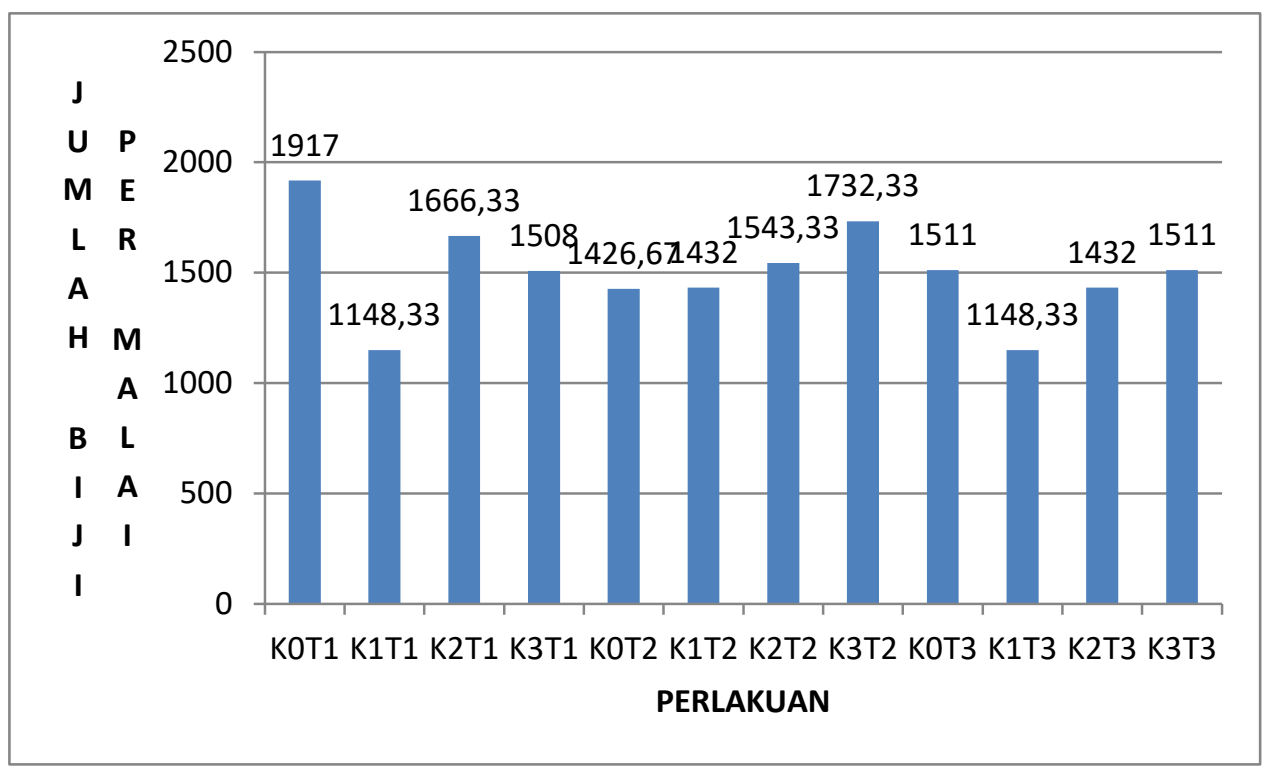

Diagram Pemberian dosis limbah ampas kopi dan macam media tanam terhadap berat kering biji per malai menunjukkan bahwa berat kering biji tertinggi pada perlakuan (K0T1 ) tanpa limbah ampas kopi dengan media tanam campuran tanah, pupuk kandang yaitu 76,83 g, sedangkan terendah pada (K1T1 ) dosis limbah ampas kopi 5 g/l dengan media tanam campuran tanah, pupuk kandang dan pada (K1T3 ) dosis limbah ampas kopi 5 g/l dengan media tanam campuran tanah, pupuk kandang , pasir yaitu 41,79 g 


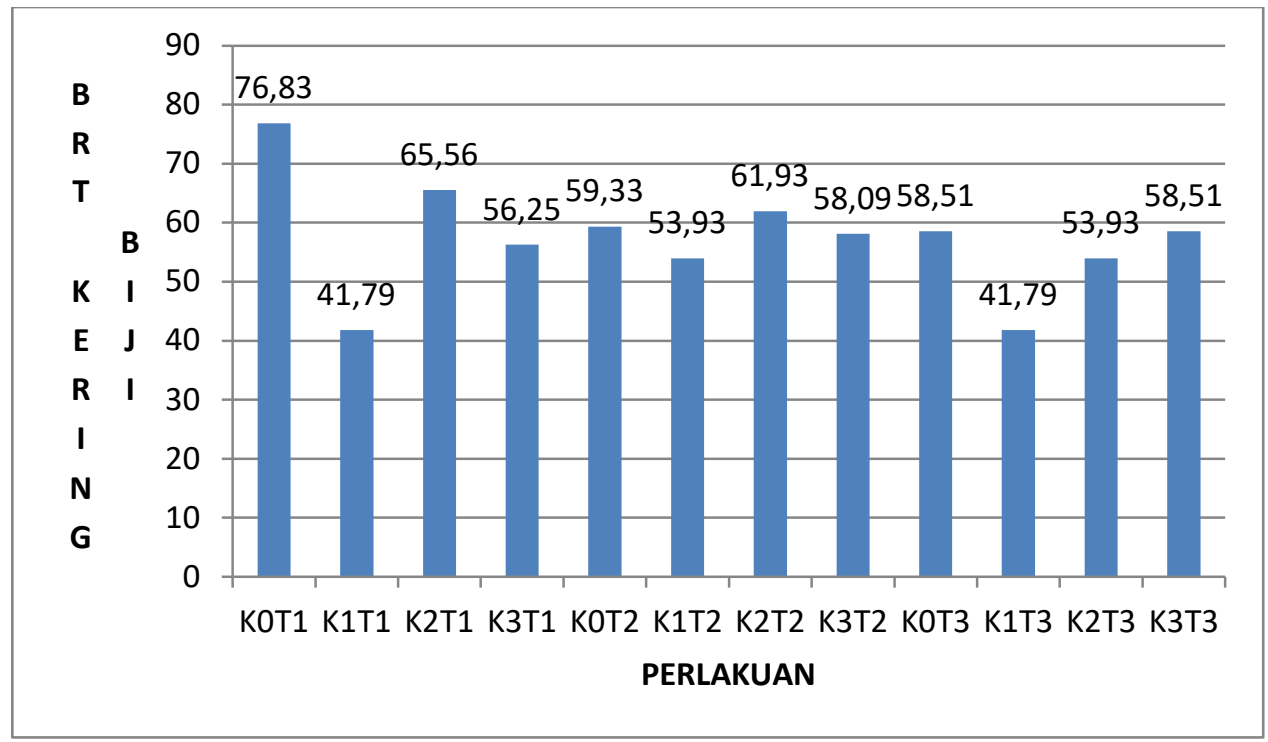

Diagram Pemberian limbah ampas kopi dan macam media tanam terhadap berat kering 100 biji menunjukkan bahwa berat kering 100 biji terbesar pada perlakuan (K0T2 ) tanpa limbah ampas kopi dengan media tanam campuran tanah, pupuk kandang dan sekam yaitu 4,14 g, sedangkan terendah pada (K3T2 ) dosis limbah ampas kopi 15 g/l dengan media tanam campuran tanah, pupuk kandang dan sekam yaitu 3,33 g.

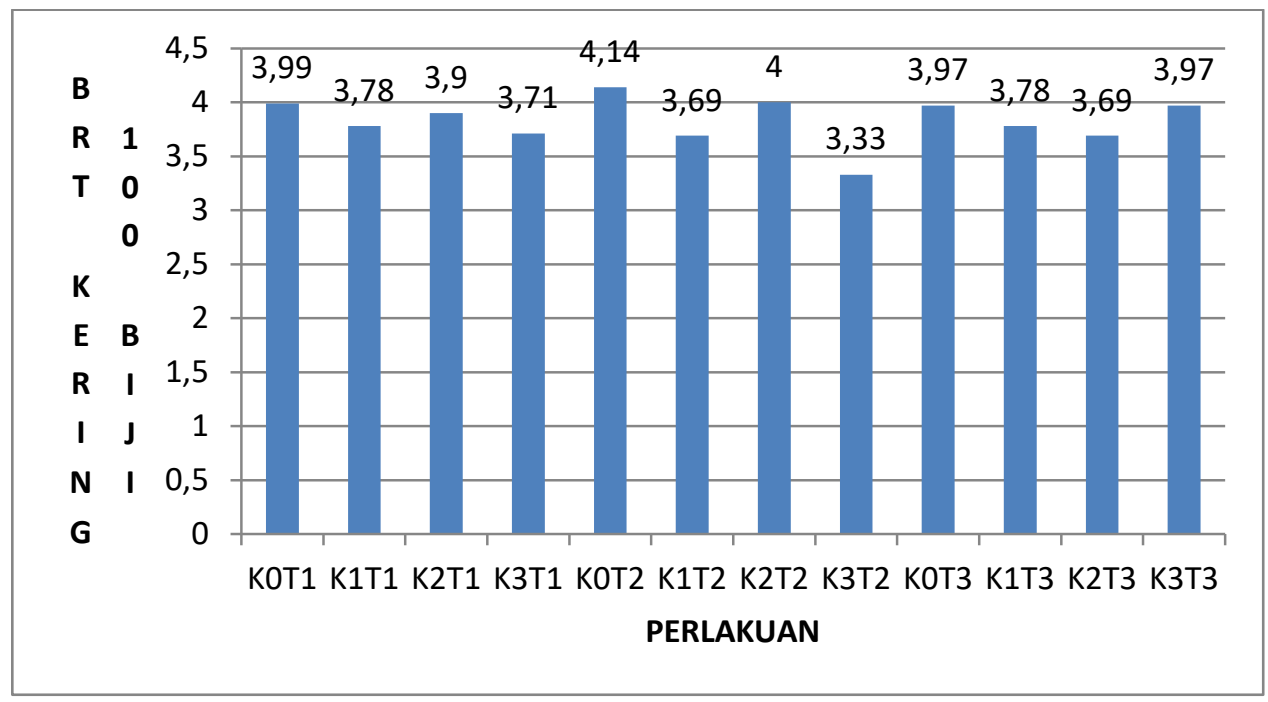

\section{KESIMPULAN.}

1. Pemberian dosis limbah ampas kopi berpengaruh terhadap berat segar brangkasan dan berat kering biji per malai.

2, Pemberian macam media tanam tidak berpengaruh terhadap semua parameter pengamatan.

3, Tidak terdapat interaksi antara pemberian dosis limbsh ampas kopi dan macam media tanam terhadap semua parameter pengamatan tanaman sorgum 


\section{DAFTAR PUSTAKA}

Adikasari, Ria. 2012. Pemanfaatan Ampas Teh dan Ampas Kopi sebagai Tambahan Nutrisi pada Pertumbuhan Tanaman Tomat (Solanum lycopersicum). Surakarta: FKIP UMS.

Agoes, N dan Lisdiana, 1994. Memilih dan Mengolah Sayur. Penebar Swadaya, Jakarta. 97 hal.

Anonim.2012 a.Media Tanam Hidroponik Dari Arang Sekam. igoywakaranai.blogspot.com.

Anonim. 2012 b Cara Unik Menyuburkan Tanaman.

http://tipspetani.blogspot.co.id/2012/12/cara-unik-menyuburkan-tanaman.html

Anonim.2016. Peluang Sorgum Untuk Pangan. http://tabloidsinartani.com/content/read/peluang-sorgum-untuk-pangan/

Anonim. 2017. Kopi bisa jadi Kompos Pupuk Tanaman.

http://www.kopimat.com/2017/07/wah-kopi-bisa-jadi-kompos-pupuk-tanaman.html

Cahyono, B. 2008. Tomat, Usaha tani dan Penanganan Pascapanen. Yogyakarta: Kanisus.

Darmawijaya, Isa, M. 1990. Klasifikasi Tanah. Fakultas Pertanian. Jogja: Universitas Gadjah mada

Dwijoseputro, D. 1986. Pengantar Fisiologi Tumbuhan. Jakarta: Gramedia, $232 \mathrm{hlm}$.

Egli, D.B. 1999. Varition in Leaf Starch and Sink Limition During Seed Filling in Soybean. Crop Sci. 39:1361-1368.

Eka, Afiyanti, R., dan Triyono, Bagus, S. 2016. Analisis Pertumbuhan Tanaman Kedelai (Glycine max. L) Varietas Grobogan pada Kondisi Cekaman Genangan.

Lakitan, B. 1996. Fisiologi Pertumbuhan dan Perkembangan Tanaman. Jakarta: PT. Raja Gerindo Persada.

Novizan, 2002. Petunjuk Pemupukan yang Efektif. Agromedia Pustaka, Jakarta .114 hal.

Pambudi, J. 2000. Potensi Teh Sebagai Sumber Zat Gizi dan Perannya Dalam Kesehatan. Prosiding Seminar Sehari Teh Untuk Kesehatan. Bandung : Pusat Penelitian Teh dan Kina Gambung

Sari, Purnama Beti. 2016. Pengaruh Komposisis Media Tanam dan Nitrogen 
Terhadap Pertumbuhan Serta Hasil Tanaman Sawi Pak Choi (Brassica rapa $L$ var. chinensis)

Sarief, S., 1989. Kesuburan dan Pemupukan Tanah Pertanian. Pustaka Buana , Bandung. 197 hal.

Soegiman. 1992 Ilmu Tanah, Terjemahan Buckman HO and N C Brady. 1962. The Nature and Pro[erties of Soil. Jakarta: Bhratara Karya Aksara. 788 hal.

Sofyadi Eddy. 2011 Aspek Budidaya-Prospek-Kendala-dan-Solusi-

Pengembangan-Sorgum di Indonesia

https://edysof.wordpress.com/2011/04/21/aspek-budidaya-prospek-kendala- dansolusi-pengembangan-sorgum-di-indonesia

Sunarto. 2004. Efesiensi Pemanfaatan Energi Cahaya Matahari Oleh Fitoplanktok dan Fotosintesis

Syarief, S. 1993. Ilmu Tanah Pertanian. Bandung: Pustaka Buana

Sutejo, MM. 2003. Pupuk dan Cara Pemupukan, Jakarta: Bina Aksara. 177 hal.

Tohari, Libria, dan W. Endang, S. 2004. Pengaruh Intensitas Cahaya dan Kadar Daminosida terhadap Iklim Mikro dan Pertumbuhan Tanaman. Ilmu Pertanian 2, 33-42 